\title{
Unfolded protein response in cancer: the Physician's perspective
}

\author{
Xuemei Li ${ }^{1}$, Kezhong Zhang ${ }^{2}$, Zihai $\mathrm{Li}^{3^{*}}$
}

\begin{abstract}
The unfolded protein response (UPR) is a cascade of intracellular stress signaling events in response to an accumulation of unfolded or misfolded proteins in the lumen of the endoplasmic reticulum (ER). Cancer cells are often exposed to hypoxia, nutrient starvation, oxidative stress and other metabolic dysregulation that cause ER stress and activation of the UPR. Depending on the duration and degree of ER stress, the UPR can provide either survival signals by activating adaptive and antiapoptotic pathways, or death signals by inducing cell death programs. Sustained induction or repression of UPR pharmacologically may thus have beneficial and therapeutic effects against cancer. In this review, we discuss the basic mechanisms of UPR and highlight the importance of UPR in cancer biology. We also update the UPR-targeted cancer therapeutics currently in clinical trials.
\end{abstract}

\section{The unfolded protein response: mechanism}

During tumorigenesis, the high proliferation rate of cancer cells requires increased activities of ER machinery in facilitating protein folding, assembly, and transport. Other pathologic stimuli can interrupt the protein folding process and subsequently cause accumulation of unfolded or misfolded proteins in the ER, a condition referred to as "ER stress" [1-5]. These pathologic stimuli include those that cause ER calcium depletion, altered glycosylation, nutrient deprivation, oxidative stress, DNA damage, or energy perturbation or fluctuations. In order to handle the accumulation of the unfolded or misfolded proteins, the ER evolves a group of signal transduction pathways, collectively termed the unfolded protein response (UPR), to alter transcriptional and translational programs to maintain ER homeostasis [6-8].

UPR has two primary functions: 1) to initially restore normal function of the cell by halting protein translation and activating the signaling pathways that lead to increased production of molecular chaperones involved in protein folding $[9,10]$; 2) to initiate apoptotic pathways to remove the stressed cells when the initial objectives are not achieved within a certain time lapse or the disruption is prolonged $[11,12]$.

\footnotetext{
* Correspondence: zihai@musc.edu

${ }^{3}$ Department of Microbiology \& Immunology; Medical University of South Carolina, Charleston, SC 29425, USA

Full list of author information is available at the end of the article
}

As a part of the UPR program, ER-associated Protein Degradation (ERAD) is responsible for the degradation of aberrant or misfolded proteins in the ER, providing an important protein folding "quality control" mechanism. During the process of ERAD, molecular chaperones and associated factors recognize and target substrates for retrotranslocation to the cytoplasm, where they are polyubiquitinated and degraded by the $26 \mathrm{~S}$ proteasome [13]. ERAD is essential for maintaining ER homeostasis, and the disruption of ERAD is closely associated with ER stress-induced apoptosis [14].

Proteasomal degradation and autophagy have been identified as two main mechanisms in charge of protein clearance in stressed cells. Proteasomal degradation digests soluble ubiquitin-conjugated proteins. Autophagy involves cytoplasmic components engulfed within a double membrane vesicle (autophagosome). The maturation of these vesicles may fuse with lysosomes, which leads in turn to the degradation of the autophagosome components by the lysosomal degradative enzymes. Conditions that induce ER stress also lead to induction of autophagy [15]. Activation of the IRE1, phosphorylation of eIF $2 \alpha$, and ER $\mathrm{Ca}^{2+}$ release can all regulate autophagy. Activation of autophagy after ER stress can be either cell-protective or cytotoxic. Persistent ER stress can switch the cytoprotective functions of UPR and autophagy into cell death programs. Some antitumoral agents (e.g., cannabinoids) activate ER stress and
Ciomed Central

() 2011 Li et al; licensee BioMed Central Ltd. This is an Open Access article distributed under the terms of the Creative Commons Attribution License (http://creativecommons.org/licenses/by/2.0), which permits unrestricted use, distribution, and reproduction in any medium, provided the original work is properly cited. 
autophagy as the primary mechanism to promote cancer cell death [16-18].

\subsection{The unfolded protein response pathways}

On aggregation of unfolded proteins, GRP78 (known also as the immunoglobulin heavy chain binding protein, or $\mathrm{BiP}$ ), one of the most abundant ER luminal chaperones, binds to unfolded proteins and dissociates from the three membrane-bound ER stress sensors. These stress sensors include pancreatic ER kinase (PKR)-like ER kinase (PERK), activating transcription factor 6 (ATF6), and inositol-requiring enzyme 1 (IRE1). The dissociation of GRP78 from these stress sensors allows their subsequent activation (Figure 1). It has been proposed that the activation of the ER stress sensors may occur sequentially, with PERK being the first, rapidly followed by ATF6, and IRE1 may be activated last [19].

Activated PERK blocks general protein synthesis by phosphorylating eukaryotic initiation factor $2 \alpha$ (eIF2 $\alpha$ ), which suppress mRNA translation. Reduced global translation also leads to reduction of key regulatory proteins that are subject to rapid turnover, facilitating activation of transcription factors such as $\mathrm{NF} \kappa-\mathrm{B}$ during cellular stress [4]. However, selective translation of some proteins is activated, including ATF4, which occurs through an alternative translation pathway. ATF4, being a transcription factor, translocates to the nucleus and induces the transcription of genes required to restore ER homeostasis. Activation of PERK is initially protective and crucial for survival during mild stress. However, it leads to the induction of CHOP (C/EBP homologous protein), an important element of the switch from proadaptive to pro-apoptotic signaling [20-24].

PERK-mediated translational repression is transient and is followed by translational recovery and enhanced expression of genes that increase the capacity of the ER to process client proteins. P58 ${ }^{\mathrm{IPK}}$ induction during the ER-stress response represses PERK activity and plays a functional role in the expression of downstream markers of PERK activity in the later phase of the ER-stress response. P58 ${ }^{\mathrm{IPK}}$, GADD34 and TRB3, are reported to be involved in switching off the PERK mediated pathway. Blocking this protective pathway can be a central element of the switch from adaptation to apoptosis $[19,25]$.

ATF6 is activated by regulated intramembrane proteolysis after its translocation from the ER to the Golgi apparatus [26]. Active ATF6 is also a transcription

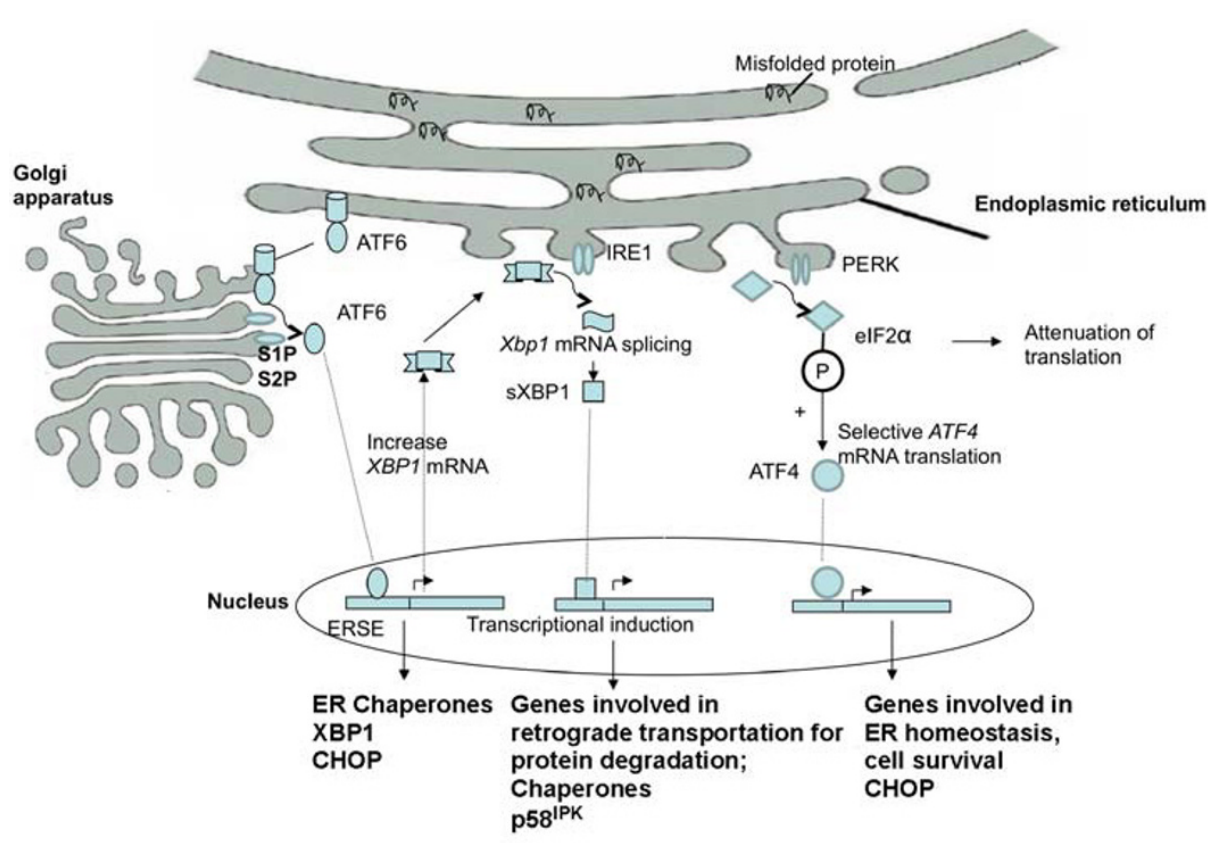

Figure 1 Signal transduction events associated with ER stress and UPR. Upon accumulation of unfolded or misfolded proteins in the ER three major ER stress sensors, PERK, ATF6 and IRE1, are activated following their dissociation from the ER chaperone GRP78. Activated PERK phosphorylates eukaryotic initiation factor $2 \alpha$ (elF2 $\alpha$ ), which suppresses global mRNA translation but activates ATF4 translation. ATF4 translocates to the nucleus and induces the transcription of genes required to restore ER homeostasis. Activation of PERK also leads to the induction of CHOP (C/EBP homologous protein), which is involved in pro-apoptotic signaling. ATF6 is activated by proteolysis mediated by proteases S1P and S2P after its translocation from the ER to the Golgi apparatus. Active ATF6 translocates to the nucleus and regulates the expression of ER chaperones and X box-binding protein 1 (XBP1) to facilitate protein folding, secretion, and degradation in the ER. Xbp1 mRNA undergoes unconventional mRNA splicing carried out by IRE1. Spliced XBP1 protein (SXBP1) translocates to the nucleus and controls the transcription of chaperones, the co-chaperones and the PERK-inhibitor P58 ${ }^{\mathrm{IPK}}$, as well as genes involved in protein degradation. 
factor that regulates the expression of ER chaperones and X box-binding protein 1 (XBP1), another UPRtrans-activator. The target genes of ATF6 and XBP1 have been shown to be involved in protein folding, secretion, and degradation in the ER [27,28].

To achieve its active form, Xbp1 mRNA must undergo a non-conventional mRNA splicing, which is carried out by IRE1 $\alpha$. IRE1 $\alpha$ protein is a type I transmembrane protein that contains both a Ser/Thr kinase domain and an endoribonuclease domain. The endoribonuclease domain processes an intron from the $X b p 1$ mRNA. Spliced XBP1 protein (XBP1s) translocates to the nucleus to activate the transcription of the genes encoding protein chaperones or folding enzymes involved in protein folding, secretion, or ERAD. Ablation of IRE1 $\alpha$ in mice produces an embryonic lethal phenotype. It has been demonstrated that both processes of ATF6 activation and the IRE1 $\alpha$-mediated splicing of XBP1 mRNA are required for full induction of the UPR [29-31].

\subsection{ER stress-induced apoptosis}

The adaptive responses to the accumulation of unfolded or misfolded proteins in the ER provide initial protection from cell death. But persistent or excessive ER stress can trigger cell death, typically through apoptosis. Both mitochondria-dependent and -independent pathways have been proposed for ER stress-induced apoptosis [32,33].

The mitochondria-dependent pathways involve proapoptotic cascades that culminate in cytochrome $c$ release. CHOP (C/EBP homology protein) is one of the proteins involved, which heterodimerizes with several $\mathrm{C} /$ EBP family members to regulate their transcriptional activity [34]. CHOP is downstream of phosphorylation cascade of PERK and eIF- $2 \alpha$. CHOP has a role in the induction of cell death by promoting protein synthesis and oxidation in the stressed ER. It modulates the Bcl-2 family of proteins, GADD34 (growth arrest and DNA damage inducible protein 34), and TRB3 (tribblesrelated protein 3 ), among other downstream proteins. After transcriptional activation by ATF4, CHOP directly activates GADD34, which promotes ER client protein biosynthesis by dephosphorylating phospho-Ser 51 of the $\alpha$ subunit of eIF- $2 \alpha$ in stressed cells $[35,36]$. Additionally, it has been suggested that $\mathrm{CHOP}$ upregulates pro-apoptotic members of the BCL2 family (BAK/BAD) and downregulates the anti-apoptotic members (BCL2), causing subsequent damage to the mitochondrial membrane and releasing cytochrome $c$ into the cytosol. The released cytochrome $c$ in turn activates cytosolic apoptotic protease activating factor1 (APAF1), which then activates the downstream caspase-9 and caspase-3dependent cascade [37].

A number of ER stress conditions can cause calcium release from the ER to the cytosol, Increases in cytosolic calcium can also cause activation of calpain, which induces cleavage of procaspase-12 [38]. Once activated, the catalytic subunits of caspase- 12 are released into the cytosol, where they activate the caspase- 9 cascade in a cytochrome $c$ independent manner [39].

It has also been suggested that activated IRE1a can recruit tumor-necrosis factor receptor associated factor 2 (TRAF2), which activates procaspase- 4 as a mitochondria-independent apoptotic response. Both pathways ultimately lead to the activation of the caspase cascade mediated through caspase- 9 and caspase- 3 , resulting in cell death [40].

\section{The unfolded protein response and its effect on tumorigenesis}

A broad range of cancer-types rely on ER protein folding machinery to correctly fold key signaling pathway proteins [41]. ER stress and the UPR are highly induced in various tumors. Accumulating evidence has demonstrated that the UPR is an important mechanism required for cancer cells to maintain malignancy and therapy resistance. Identifying the UPR components that are activated or suppressed in malignancy and exploring cancer therapeutic potentials by targeting the UPR are very active research areas [7].

The UPR pathways are activated in a great variety of tumor types, and have been demonstrated to be essential for tumor cells to survive the unfriendly tumor microenvironment. There are evidence of over-expression of XBP1s (excision of a 26 nucleotide unconventional intron from XBP-1 mRNA), activation of ATF6, phosphorylation of eIF- $2 \alpha$, induction of ATF4 and CHOP in a variety of cancer cells. The ER chaperones GRP78/BiP, glucoseregulated protein 94 (GRP94, also known as gp96 or HSP90b1) and GRP170 were also upregulated [42]. These studies were conducted in primary human tumor cells or cell lines, and animal models with breast tumor, hepatocellular carcinoma, gastric tumor, and esophageal adenocarcinoma [42-52]. UPR and stress response in general have also been implicated in participating in inflammation-induced oncogenesis [53].

UPR is required for tumorigenesis. Animal study demonstrated that XBP1 was required for tumor growth in vivo. $\mathrm{Xbp1}^{-1-}$ and $\mathrm{Xbp1-knockdown}$ cells did not form tumors in mice even though their growth rate and secretion of vascular endothelial growth factor (VEGF) in response to in vitro hypoxia treatment were not decreased [46]. ER stress can also induce anti-apoptotic responses. The activation of glycogen synthase kinase $3 \beta$ (GSK $3 \beta$ ) leads to phosphorylation of p53, which increases its degradation [54], therefore protects cancer cells from p53 dependent apoptosis. In addition, $\mathrm{NF} \kappa \mathrm{B}$ is activated during ER stress to induce anti-apoptotic responses [55]. 
Heat shock proteins were reported to assist cancer cell adaptation to oncogenesis-associated stress either by repairing damaged proteins (protein refolding) or by degrading them. Heat shock proteins have also been implicated in the control of cell growth, and in resistance to various anticancer treatments that induce apoptosis. For example, HSP90 interacts with several key proteins in promoting prostate cancer progression, including wild-type and mutated AR, HER2, ErbB2, Src, Abl, Raf and Akt [56,57]. GRP78/BiP, expressed at high levels in a variety of tumors, confers drug resistance in both proliferating and dormant cancer cells. Genetically engineered animal model with reduced GRP78 level significantly impedes tumor growth. Three major mechanisms were proposed for GRP78 mediated cancer progression: enhancement of tumor cell proliferation, protection against apoptosis, and promotion of tumor angiogenesis [58-60].

ER stress has been implicated in different stages of tumor development. The proposed mechanism is, during early tumorigenesis and before angiogenesis occurs, that activation of the UPR induces a G1 cell cycle arrest and activation of $\mathrm{p} 38$, both of which promote a dormant state. If the apoptotic signals are induced by the UPR during this stage of tumor development, cancer cells with mutated elements of the apoptotic pathway may evade the alternative fate of death. ER stress also induces anti-apoptotic NF- $\kappa \mathrm{B}$ and inhibits p53-dependent apoptotic signals. If the balance of early cancer development tilts against cell death, ER stress can further promote the aggressive growth of these cancer cells by enhancing their angiogenic ability. One example is the increased VEGF secretion through induction of GRP170, a BiP-like protein that acts as a chaperone for VEGF [37].

\section{The unfolded protein response and its effect on disease prognosis}

GRP78 is a marker of UPR activation. An elevated GRP78 level generally correlates with higher pathologic grade, recurrence rate, and poor survival in patients with breast, liver, prostate, colon, and gastric cancers; though there are conflicting reports on lung cancer. Neuroblastoma is an apparent exception with correlation of GRP78 abundance with earlier stage and better prognosis [59,61-64].

A retrospective cohort study of 127 stage II and III breast cancer patients who were treated with Adriamycin-based chemotherapy, showed association between GRP78 positivity and shorter time to tumor recurrence [59]. Another breast cancer study showed that the UPR is activated in the majority of breast cancers and confers resistance to chemotherapy and endocrine therapy. Estrogen is known to stimulate UPR in vitro. UPR activation interacts with estrogen response elements and may regulate tumor growth [65].

Overexpression of GRP94 and GRP78 has been observed more often in patients with poorly differentiated lung cancer than in well or moderately differentiated tumors [66]. According to a study on adenocarcinoma of the esophagus, GRP78 and GRP94 mRNA were elevated in all tumors. Increased expression of GRP78 may be responsible for controlling local tumor growth in early tumor stages, while high expression of GRP78 and GRP94 in advanced stages was believed to be dependent on other cellular stress reactions such as glucose deprivation, hypoxia, or the hosts' immune response [67]. Up-regulated expression of GRP78 and GRP94 was also reported in gastric carcinoma, which was associated with aggressive tumor growth and poor prognosis [68].

Heterozygous GRP78 mice with half of wild-type GRP78 level are comparable to WT siblings in tumor growth and development. The tumor progression was significantly impeded in these mice as exemplified by a longer latency period, reduced tumor size, and increased tumor apoptosis. Reduction of GRP78 in cancer xenograft animal model inhibited tumor formation and growth [69].

$\mathrm{XBP} 1 \mathrm{~s}$ is a trans-activator of UPR signaling. High $\mathrm{XBP} 1 \mathrm{~s}$ level is associated with increased tumor growth, resistance to anti-estrogen therapy and poor patient survival $[70,71]$. In a B cell-specific XBP1s-overexpressing transgenic mouse model, multiple myeloma developed spontaneously, highlighting the importance of UPR in tumorigenesis [72].

\section{Therapeutic targeting of unfolded protein response in cancer}

The accumulation of unfolded proteins triggers the UPR, which mediates the inhibition of general protein synthesis but increases expression of several transcription factors that activate genes encoding ER stress-inducible molecular chaperones, transcription factors and signal pathway proteins. Most normal cells are not undergoing active "stress" response, and the UPR pathways remain in a quiescent state in these cells. This discrepancy between tumor cells and normal cells offers an advantage for the agents that target the UPR to achieve the specificity in cancer therapy. The therapeutic potential of targeting the UPR components in cancer mainly involves two approaches: induction of accumulation of misfolded protein in ER to overload the unfolded protein response, and inhibition of UPR adaptive and antiapoptotic pathways to prevent cells from adapting to stressful conditions leading to cell death. In the following paragraphs, we will discuss some examples of agents that are being developed as cancer therapeutics (Table 1). 
Table 1 Examples of UPR-targeted cancer drugs in development

\begin{tabular}{|c|c|c|c|c|}
\hline Drug & $\begin{array}{l}\text { Classification/ } \\
\text { Mechanism }\end{array}$ & $\begin{array}{l}\text { Development } \\
\text { Stage }\end{array}$ & Disease Indication & Reference \\
\hline Bortezomib & $\begin{array}{l}\text { Proteasome } \\
\text { inhibitor }\end{array}$ & FDA approved & Multiple myeloma, mantle-cell lymphoma & San et al. [97] \\
\hline $\begin{array}{l}\text { NPI-0052 } \\
\text { (salinosporamide A) }\end{array}$ & $\begin{array}{l}\text { Irreversible } \\
\text { proteasome } \\
\text { inhibitor }\end{array}$ & $\begin{array}{l}\text { Phase I clinical } \\
\text { trials }\end{array}$ & Multiple Myeloma, Advanced malignancies & Chauhan et al. [98] \\
\hline Carfilzomib (PR-171) & $\begin{array}{l}\text { Selective } \\
\text { proteasome } \\
\text { inhibitor }\end{array}$ & $\begin{array}{l}\text { Phase I, II, III } \\
\text { clinical trials }\end{array}$ & $\begin{array}{l}\text { Multiple Myeloma, Waldenstrom's } \\
\text { Macroglobulinemia }\end{array}$ & $\begin{array}{l}\text { O'Connor et al. [99] Lee } \\
\text { et al. [100] }\end{array}$ \\
\hline PS-341 & $\begin{array}{l}\text { Selective } \\
\text { proteasome } \\
\text { inhibitor }\end{array}$ & Phase II & Multiple Myeloma & Richardson et al. [101] \\
\hline CEP-18770 & $\begin{array}{l}\text { Proteasome } \\
\text { inhibitor }\end{array}$ & $\begin{array}{l}\text { Phase I, II } \\
\text { clinical trials } \\
\text { and preclinical } \\
\text { studies }\end{array}$ & multiple myeloma, Non- Hodgkin's lymphoma & Piva et al. [102] \\
\hline $\begin{array}{l}\text { Tanespimycin (17-AAG, (17- } \\
\text { Allylamino-17- } \\
\text { demethoxygeldanamycin), } \\
\text { KOS-953) }\end{array}$ & HSP90 Inhibitor & $\begin{array}{l}\text { Phase I, II, III } \\
\text { clinical trials }\end{array}$ & $\begin{array}{l}\text { Gastrointestinal stromal tumors, breast cancer, } \\
\text { gynecological, leukemia, lymphoma, melanoma, } \\
\text { prostate, renal, thyroid carcinoma, melanoma }\end{array}$ & $\begin{array}{l}\text { Richardson et al. [103,104] } \\
\text { Heath et al. [105] Pacey et al. } \\
{[106]}\end{array}$ \\
\hline $\begin{array}{l}\text { Alvespimycin (KOS-1022, } \\
\text { 17-DMAG) }\end{array}$ & HSP90 Inhibitor & $\begin{array}{l}\text { Phase I clinical } \\
\text { trials and } \\
\text { preclinical } \\
\text { studies }\end{array}$ & Acute myeloid leukemia, advanced carcinoma & $\begin{array}{l}\text { Kummar et al. [107] Lancet } \\
\text { et al. [108] Pamanathan et al. } \\
\text { [109] Zismanov et al. [110] }\end{array}$ \\
\hline Retaspimycin (IPI-504) & HSP90 Inhibitor & $\begin{array}{l}\text { Phase II clinical } \\
\text { trials }\end{array}$ & $\begin{array}{l}\text { Gastrointestinal stromal tumors, nonsmall cell } \\
\text { lung, prostate }\end{array}$ & Hanson et al. [111] \\
\hline $\mathrm{PU}-\mathrm{H} 71$ & HSP90 Inhibitor & $\begin{array}{l}\text { Preclinical } \\
\text { studies }\end{array}$ & $\begin{array}{l}\text { Breast cancer, myeloma, myeloproliferative } \\
\text { disorder }\end{array}$ & $\begin{array}{l}\text { Usmani et al. [84] Caldas- } \\
\text { Lopes et al. [112] Marubayashi } \\
\text { et al. [113] }\end{array}$ \\
\hline SNX-2112 & HSP-90 inhibitor & $\begin{array}{l}\text { Preclinical } \\
\text { studies }\end{array}$ & Gastric cancer & $\begin{array}{l}\text { Bachleitner-Hofmann, } \\
\text { et al. [114] }\end{array}$ \\
\hline Eeyarestatin I (Eerl) & $\begin{array}{l}\text { Inhibitor of ER- } \\
\text { associated } \\
\text { degradation } \\
\text { (ERAD) }\end{array}$ & $\begin{array}{l}\text { Preclinical } \\
\text { studies }\end{array}$ & & Cross et al. [115] \\
\hline Versipelostatin & GRP78 inhibitor & $\begin{array}{l}\text { Preclinical } \\
\text { studies }\end{array}$ & & Matsuo et al. [87] \\
\hline $\begin{array}{l}\text { (-)-epigallocatechin gallate } \\
\text { (EGCG) }\end{array}$ & GRP78 inhibitor & $\begin{array}{l}\text { Preclinical } \\
\text { studies }\end{array}$ & Breast carcinoma & Luo et al. [116] \\
\hline $\begin{array}{l}\text { Epidermal growth factor } \\
\text { (EGF)-SubA }\end{array}$ & $\begin{array}{l}\text { GRP78-targeting } \\
\text { cytotoxin }\end{array}$ & $\begin{array}{l}\text { Preclinical } \\
\text { murine animal } \\
\text { models }\end{array}$ & Prostate tumor & Backer et al. [90] \\
\hline Irestatins & IRE1 $\alpha$ inhibitor & $\begin{array}{l}\text { Preclinical } \\
\text { studies }\end{array}$ & Multiple Myeloma, & Feldman et al. [117] \\
\hline $\begin{array}{l}\text { Delta(9)- } \\
\text { Tetrahydrocannabinol (THC) }\end{array}$ & $\begin{array}{l}\text { Cannabinoid, } \\
\text { activates ER } \\
\text { stress and } \\
\text { autophagy }\end{array}$ & $\begin{array}{l}\text { Phase I clinical } \\
\text { trial }\end{array}$ & Glioblastoma multiforme & Guzmán et al. [118] \\
\hline
\end{tabular}

\subsection{Targeting induction of unfolded protein response Proteasomal inhibitor}

Proteasomal degradation of misfolded proteins retrotranslocated from the ER to the cytosol represents the final step in ERAD. Bortezomib (Velcade, PS-341), a boronic acid derivative, was the first proteosome inhibitor to be developed successfully for anti-cancer therapy. Although the drug probably has multiple mechanisms of action, proteasomal inhibition causes an additional burden of unfolded proteins in the ER. This explains the high efficacy of bortezomib treatment against types of cancer cells in which the ER is already predisposed with a considerable protein load. In multiple myeloma cell lines, Bortezomib rapidly induced components of the proapoptotic UPR, including PERK, the ER stress-specific eIF- $2 \alpha$ kinase, ATF4 and its proapoptotic target, 
CHOP. The amount of immunoglobulin subunits retained within multiple myeloma cells correlated with their sensitivity to proteasomal inhibitors [73].

Bortezomib treatment has a cytotoxic effect on various other cancer types such as breast, colorectal, ovarian, pancreatic, prostate, lung and oral cancer. It has been approved by the FDA for the treatment of relapsed multiple myeloma, and recently for relapsed mantle cell lymphoma. Combination chemotherapy regimens with Bortezomib have been developed, leading to unprecedented high remission rates in the frontline treatment or in the relapsed setting for multiple myeloma. The combination of proteasome inhibition with novel targeted therapies is an emerging field in oncology [74].

\section{ERAD inhibitors}

As a part of ER quality control mechanism, misfolded or unassembled proteins are retained in the ER and subsequently degraded by ERAD. In the ERAD pathway, molecular chaperones and lectin-like proteins are involved in the identification of misfolded proteins. ERresident reductases cleave disulfide bonds in these proteins to facilitate retrograde transport to the cytosol. Furthermore, the $\mathrm{AAA}(+)$ adenosine triphosphatase withdraws them from the retrotranslocation channel to the cytosol where they are degraded by the ubiquitin/ proteasome system [75].

Defects in ERAD cause the accumulation of misfolded proteins in the ER and thus trigger ER stress and UPR. Eeyarestatin I (EerI), a chemical inhibitor that can block ERAD, has been shown to have preferential cytotoxic activity against cancer cells. EerI targets p97 (a cytosolic ATPase involved in polyubiquitinated proteins transportation) complex to inhibit deubiquitination of p97-associated ERAD substrates, which is required for the degradation process [76].

\section{PDI inhibitors}

Protein disulfide isomerase (PDI) is one of the most abundant ER proteins and maintains a sentinel function in organizing accurate protein folding. PDIs are key protein folding catalysts activated during UPR [77]. Treatment of cells with $\mathrm{O}(2)$-[2,4-dinitro-5-(N-methyl$\mathrm{N}$-4-carboxyphenylamino)phenyl]1-(N,N- methylamino)diazen-1-ium-1,2-diolate (PABA/NO) resulted in a dose-dependent increase in intracellular nitric oxide that caused S-glutathionylation and therefore inhibition of PDI. PABA/NO activates the UPR and causes translational attenuation, phosphorylation and activation of PERK, and its downstream effector eIF2 $\alpha$ in human leukemia (HL60) and ovarian cancer cells (SKOV3). There was also evidence for Xbp1 mRNA splicing and transcriptional activation of the ER resident chaperones GRP78 and GRP94. Stimulating UPR may be linked with the cytotoxic potential of PABA/NO in cancer cells [78].

\subsection{Targeting ER chaperones/heat shock proteins HSP9O inhibitor}

Under conditions of cellular stress, cells upregulate chaperones to prevent protein misfolding and degradation. All three ER-membrane bound sensors are heavily reliant on the protein chaperone functions of the HSP90 complex. The interaction between the heat shock protein family and the key proteins in the UPR pathway may, in part, be mediated by their destabilizing effect on UPR proteins and increased accumulation of misfolded proteins.

Myeloma cell study demonstrated that HSP90 inhibitors, 17AAG (17-allylamino-17-demethoxygeldanamycin) and radicicol, similar to tunicamycin (TM) and thapsigargin (TG) (known UPR activators), are capable of activating all three branches of the UPR. All drugs inhibited proliferation and increased expression levels of the molecular chaperones BiP and GRP94. Unlike TG and TM, the HSP90 inhibitors activate a caspase-dependent cell death pathway [79]. 17AAG can induce the formation of 'intracellular inclusions' in breast cancer cells. In myeloma cells, these inclusions are comprised of aggregations of misfolded immunoglobulin light chains and analysis of protein samples taken from 17AAG-treated cells suggest that exposure to HSP90 inhibitors alters the expression of LC3 (microtubule-associated protein 1 light chain 3, a reliable marker for autophagosome formation), consistent with autophagosome formation [80-82].

Study demonstrated analogous effects of HSP90 inhibitor, 17AAG in the colon cancer cell line HCT116 indicating that they utilize the UPR in a similar manner to multiple myeloma [41]. A recent phase II trial was done using the HSP90 inhibitor, 17-AAG in fifteen melanoma patients with measurable disease. 17-AAG was administered i.v. once weekly for 6 weeks at $450 \mathrm{mg} / \mathrm{m}^{2}$. No objective responses were observed. Western blot analysis of tumor biopsies showed an increase in HSP70 and a decrease in cyclin D1 expression in the posttreatment biopsies. UPR components were not analyzed in this study. More potent HSP90 inhibitor or a formulation that are soluble and can be administered chronically for a more prolonged suppression effect on UPR may be necessary to be clinically beneficial [83]. A phase III clinical trial is ongoing to evaluate the utility of 17-AAG in multiple myeloma patients. There are also Phase II clinical trails in breast cancer and non-small cell lung carcinoma. PU-H71, a novel purine scaffold HSP90 inhibitor, has shown interesting preclinical activity against myeloma [84].

\section{Grp78/BiP inhibitor}

Levels of Grp78/BiP are commonly raised in solid tumors and cancer cell lines [85]. Versipelostatin (VST) and analogues, novel macrocyclic compound and 
GRP78/BiP inhibitor, showed promise in solid tumors [86]. VST has demonstrated selective cytotoxicity to glucose-deprived tumor cells by preventing the unfolded protein response. It was shown to inhibit GRP78 induction and the expression of the UPR transactivators $\mathrm{XBP} 1$ and ATF4. Eukaryotic initiation factor 4E-binding protein 1 (4E-BP1), a negative regulator of eukaryotic initiation factor $4 \mathrm{E}$-mediated protein translation, plays a role in the UPR-inhibitory action of VST. Aberrant activation of 4E-BP1 prevents induction of the GRP78 and ATF4 [7,87-89].

Treatment of glioma cells with another GRP78 inhibitor, epigallocatechin gallate (EGCG,) which targets the ATP-binding domain of GRP78 and blocks its UPR protective function, sensitizes glioma cells to chemotherapy agent temozolomide [85]. Additionally, an engineered fusion protein, epidermal growth factor-SubA (EGFSubA), a chaperone-targeting cytotoxin, was reported to be highly toxic to growing and confluent epidermal growth factor receptor-expressing cancer cells, and its cytotoxicity is thought to be mediated by rapid cleavage of GRP78 [90].

\subsection{Inhibiting IRE1 $\alpha / X B P 1$ pathway Inhibitors of the IRE $1 \alpha / X B P 1$ pathway}

Irestatin, an inhibitor of IRE1 and the unfolded protein response, mediates inhibition of XBP1s transcription activity. The inhibition of the IRE1 endonuclease impairs the growth of malignant myeloma cells and inhibits the survival of oxygen-starved tumor cells in vitro and subcutaneous HT1080 tumor xenografts [91].

Trierixin, a new member of the triene-ansamycin group, isolated from the fermentation broth of Streptomyces sp. AC654, was shown to be a novel inhibitor of ER-stress induced cleavage of XBP1 [92]. Future work needs to be done to evaluate its activity in cancer therapy.

\subsection{Other agents affecting unfolded protein response}

IPI-504, a soluble HSP90 inhibitor, can block the unfolded protein response in multiple myeloma (MM) cells. Partial UPR is constitutively activated in plasma cell-derived MM cells. IPI-504 can potently inhibit this pathway. IPI-504 achieves this by inactivating the transcription factors XBP1 and ATF6. In addition, IPI-504 also blocks the tunicamycin-induced phosphorylation of eIF2 $\alpha$ by PERK. The inhibitory effect of IPI-504 on the UPR parallels its cytotoxic and pro-apoptotic effects on multiple myeloma cells [93].

As discussed above, autophagy is a cellular process in which cytoplasmic materials are sequestered into autophagosomes and delivered to lysosomes for degradation or recycling. It can switch from cytoprotective role to a form of programmed cell death with persistent ER stress. Tetrahydrocannabinol (THC), the main active component of marijuana, induces human glioma cell death through stimulation of autophagy. THC induced autophagy is associated with an increased phosphorylation of eIF2 $\alpha$ [94].

Resveratrol (RES), a natural plant polyphenol, is an effective inducer of cell cycle arrest and apoptosis in a variety of carcinoma cell types. In addition, RES has been reported to inhibit tumorigenesis in several animal models. RES causes cell cycle arrest and proliferation inhibition via induction of UPR in human leukemia K562 cell line [95].

The phytoestrogen zearalenone (ZEA), one of the most active naturally occurring estrogenic compounds in food and beverages, has also been shown recently to induce human leukemic cell apoptosis via endoplasmic stress and mitochondrial pathway [96].

\section{Perspectives}

We have highlighted the importance of UPR in tumorigenesis and provided an overview on the potential strategy in perturbing UPR in cancer treatment. URP promotes the ability of cancer cells to adapt to and survive the hostile microenvironment through activation of stress-response pathways and upregulation of chaperones. Targeting URP pathway represents a novel targeted anti-cancer approach with initial successes in clinical studies. Further understanding of the pathway should provide additional therapeutic opportunities.

Clearly, UPR and the associated molecular components are emerging as important potential targets for drugs that may be used in the treatment of cancer in which protein-folding and protein quality control play a key role in disease pathology. This area looks set to be a very exciting one in years to come. It is worthwhile to point out that protein quality control is fundamentally important for life. Thus targeted therapy towards UPR or other arms of protein quality control is by no means cancer-specific and toxicity-free. Of particular importance is the lack of understanding of the fundamental roles and mechanisms of protein quality control in development, organ function, the evolution and fitness of organism. Thus, as more pharmacological agents are being developed clinically, attention needs to be paid to the understanding of the basic mechanism of the regulation of unfolded protein response and to the discovery of important new players in the protein quality control for disease target.

\section{Acknowledgements}

K.Z. and Z.L. are supported by NIH grants. We thank Ms. Samantha Cronin for her secretarial support.

\section{Author details}

'Lea's Foundation Center for Hematologic Disorders and Neag Comprehensive Cancer Center, University of Connecticut School of Medicine, 
Farmington, CT 06030-1601, USA. ${ }^{2}$ Center for Molecular Medicine and Genetics, Department of Microbiology and Immunology, Wayne State University, Detroit, MI 48201, USA. ${ }^{3}$ Department of Microbiology \& Immunology; Medical University of South Carolina, Charleston, SC 29425, USA

\section{Authors' contributions}

All authors participated in the writing of this manuscript and have approved its publication.

\section{Competing interests}

The authors declare that they have no competing interests.

Received: 17 January 2011 Accepted: 23 February 2011

Published: 23 February 2011

\section{References}

1. Kaufman RJ: Stress signaling from the lumen of the endoplasmic reticulum: coordination of gene transcriptional and translational controls. Genes Dev 1999, 13:1211-1233.

2. McMillan DR, Gething MJ, Sambrook J: The cellular response to unfolded proteins: intercompartmental signaling. Curr Opin Biotechnol 1994, 5:540-545.

3. Mori K: Tripartite management of unfolded proteins in the endoplasmic reticulum. Cell 2000, 101:451-454.

4. Ron D, Walter P: Signal integration in the endoplasmic reticulum unfolded protein response. Nat Rev Mol Cell Biol 2007, 8:519-529.

5. Sidrauski $C$, Chapman $R$, Walter $P$ : The unfolded protein response: an intracellular signalling pathway with many surprising features. Trends Cell Biol 1998, 8:245-249.

6. Rutkowski DT WJ, Back SH, Kaufman RJ, et al: UPR Pathways Combine to Prevent Hepatic Steatosis Caused by ER Stress-Mediated Suppression of Transcriptional Master Regulators. Dev Cell 2008, 15(6):829-40.

7. Wang G, Yang ZQ, Zhang K: Endoplasmic reticulum stress response in cancer: molecular mechanism and therapeutic potential. Am J Trans/ Res 2010, 2:65-74.

8. Scheuner DSB, Kaufman RJ, et al: Translational control is required for the unfolded protein response and in vivo glucose homeostasis. Mol Cell 2001, 7(6):1165-76.

9. Dorner AJWL, Kaufman RJ: Increased synthesis of secreted proteins induces expression of glucose-regulated proteins in butyrate-treated Chinese hamster ovary cells. J Biol Chem 1989, 264:20602-20607.

10. Schroder MKR: The mammalian unfolded protein response. Annu Rev Biochem 2005, 74:739-789.

11. Zhang KKR: Identification and characterization of endoplasmic reticulum stress-induced apoptosis in vivo. Methods Enzymol 2008, 442:395-419.

12. Fribley AZK, Kaufman RJ: Regulation of apoptosis by the unfolded protein response. Methods Mol Biol 2009, 559:191-204.

13. Travers KPC, Wodicka L, Lockhart DL, Weissman JS, Walter P: Functional and Genomic Analyses Reveal an Essential Coordination between the Unfolded Protein Response and ER-Associated Degradation. Cell 2000, 101(3):249-258.

14. Brodsky SSVJL: One step at a time: endoplasmic reticulum-associated degradation. Nature Reviews Molecular Cell Biology 2008, 9:944-957.

15. Yorimitsu TNU, Yang Z, Klionsky DJ: Endoplasmic reticulum stress triggers autophagy. J Biol Chem 2006, 281(40):30299-304.

16. Guzman M: Cannabinoids: potential anticancer agents. Nat Rev Cancer 2003, 3:745-755.

17. Velasco G, Carracedo A, Blazquez C, Lorente M, Aguado T, Haro A, Sanchez C, Galve-Roperh I, Guzman M: Cannabinoids and gliomas. Mol Neurobiol 2007, 36:60-67.

18. Verfaillie T, Salazar M, Velasco G, Agostinis P: Linking ER Stress to Autophagy: Potential Implications for Cancer Therapy. Int J Cell Biol 2010, 930509.

19. Szegezdi E, Logue SE, Gorman AM, Samali A: Mediators of endoplasmic reticulum stress-induced apoptosis. EMBO Rep 2006, 7:880-885.

20. Heather $P$, Harding $Y Z$, Bertolotti Anne, Huiqing Zeng, David Ron: Perk Is Essential for Translational Regulation and Cell Survival during the Unfolded Protein Response. Molecular Cell 2000, 5:897-904.

21. Scheuner D, Song B, McEwen E, Liu C, Laybutt R, Gillespie P, Saunders T, Bonner-Weir S, Kaufman RJ: Translational control is required for the unfolded protein response and in vivo glucose homeostasis. Mol Cell 2001, 7:1165-1176.

22. Wek RCCD: Translational control and the unfolded protein response. Antioxid Redox Signal 2007, 9(12):2357-71, 2007 9:2357-2371.

23. Xu C, Bailly-Maitre B, Reed JC: Endoplasmic reticulum stress: cell life and death decisions. J Clin Invest 2005, 115:2656-2664.

24. Zhang K, Kaufman RJ: From endoplasmic-reticulum stress to the inflammatory response. Nature 2008, 454:455-462.

25. Yan W, Frank CL, Korth MJ, Sopher BL, Novoa I, Ron D, Katze MG: Control of PERK elF2alpha kinase activity by the endoplasmic reticulum stressinduced molecular chaperone P58IPK. Proc Natl Acad Sci USA 2002, 99:15920-15925

26. Ye J, Rawson RB, Komuro R, Chen X, Dave UP, Prywes R, Brown MS, Goldstein JL: ER stress induces cleavage of membrane-bound ATF6 by the same proteases that process SREBPs. Mol Cell 2000, 6:1355-1364.

27. Lee $A H$, Iwakoshi NN, Glimcher LH: XBP-1 regulates a subset of endoplasmic reticulum resident chaperone genes in the unfolded protein response. Mol Cell Biol 2003, 23:7448-7459.

28. Yamamoto KST, Matsui T, Sato M, Okada T, Yoshida H, Harada A, Mori K: Transcriptional induction of mammalian ER quality control proteins is mediated by single or combined action of ATF6alpha and XBP1. Dev Cell 2007, 13:365-376.

29. Lee K, Tirasophon W, Shen X, Michalak M, Prywes R, Okada T, Yoshida H, Mori K, Kaufman RJ: IRE1-mediated unconventional mRNA splicing and S2P-mediated ATF6 cleavage merge to regulate XBP1 in signaling the unfolded protein response. Genes Dev 2002, 16:452-466

30. Rao RV, Bredesen DE: Misfolded proteins, endoplasmic reticulum stress and neurodegeneration. Curr Opin Cell Biol 2004, 16:653-662.

31. Yoshida H, Matsui T, Yamamoto A, Okada T, Mori K: XBP1 mRNA is induced by ATF6 and spliced by IRE1 in response to ER stress to produce a highly active transcription factor. Cell 2001, 107:881-891.

32. Rao RV, Castro-Obregon S, Frankowski H, Schuler M, Stoka V, del Rio G, Bredesen DE, Ellerby HM: Coupling endoplasmic reticulum stress to the cell death program. An Apaf-1-independent intrinsic pathway. J Biol Chem 2002, 277:21836-21842.

33. Breckenridge DG, Germain M, Mathai JP, Nguyen M, Shore GC: Regulation of apoptosis by endoplasmic reticulum pathways. Oncogene 2003, 22:8608-8618.

34. Ron D, Habener JF: CHOP, a novel developmentally regulated nuclear protein that dimerizes with transcription factors C/EBP and LAP and functions as a dominant-negative inhibitor of gene transcription. Genes Dev 1992, 6:439-453

35. Zinszner $H$, Kuroda M, Wang X, Batchvarova N, Lightfoot RT, Remotti $H$, Stevens $\lrcorner$, Ron D: CHOP is implicated in programmed cell death in response to impaired function of the endoplasmic reticulum. Genes Dev 1998, 12:982-995.

36. Marciniak SJ, Yun CY, Oyadomari S, Novoa I, Zhang Y, Jungreis R, Nagata $K$, Harding HP, Ron D: CHOP induces death by promoting protein synthesis and oxidation in the stressed endoplasmic reticulum. Genes Dev 2004, 18:3066-3077

37. Ma $Y$, Hendershot LM: The role of the unfolded protein response in tumour development: friend or foe? Nat Rev Cancer 2004, 4:966-977.

38. Nakagawa TYJ: Cross-talk between two cysteine protease families. Activation of caspase-12 by calpain in apoptosis. J Cell Biol 2000, 150:887-894

39. Morishima N, Nakanishi K, Takenouchi H, Shibata T, Yasuhiko Y: An endoplasmic reticulum stress-specific caspase cascade in apoptosis Cytochrome c-independent activation of caspase-9 by caspase-12. J Biol Chem 2002, 277:34287-34294.

40. WU JKR: From acute ER stress to physiological roles of the Unfolded Protein Response. Cell Death Differ 2006, 13(3):374-84.

41. Davenport EL, Morgan GJ, Davies FE: Untangling the unfolded protein response. Cell Cycle 2008, 7:865-869.

42. Fernandez PM, Tabbara SO, Jacobs LK, Manning FC, Tsangaris TN, Schwartz AM, Kennedy KA, Patierno SR: Overexpression of the glucoseregulated stress gene GRP78 in malignant but not benign human breast lesions. Breast Cancer Res Treat 2000, 59:15-26.

43. Fels DR, Koumenis C: The PERK/elF2alpha/ATF4 module of the UPR in hypoxia resistance and tumor growth. Cancer Biol Ther 2006, 5:723-728.

44. Haga N, Saito S, Tsukumo Y, Sakurai J, Furuno A, Tsuruo T, Tomida A: Mitochondria regulate the unfolded protein response leading to cancer 
cell survival under glucose deprivation conditions. Cancer Sci 101:1125-1132.

45. Koumenis C, Wouters BG: "Translating" tumor hypoxia: unfolded protein response (UPR)-dependent and UPR-independent pathways. Mol Cancer Res 2006, 4:423-436.

46. Romero-Ramirez L, Cao H, Nelson D, Hammond E, Lee AH, Yoshida H, Mori K, Glimcher LH, Denko NC, Giaccia AJ, et al: XBP1 is essential for survival under hypoxic conditions and is required for tumor growth. Cancer Res 2004, 64:5943-5947.

47. Shajahan AN, Riggins RB, Clarke R: The role of X-box binding protein-1 in tumorigenicity. Drug News Perspect 2009, 22:241-246.

48. Shuda M, Kondoh N, Imazeki N, Tanaka K, Okada T, Mori K, Hada A, Arai M, Wakatsuki T, Matsubara O, et al: Activation of the ATF6, XBP1 and grp78 genes in human hepatocellular carcinoma: a possible involvement of the ER stress pathway in hepatocarcinogenesis. J Hepatol 2003, 38:605-614.

49. Song MS, Park YK, Lee JH, Park K: Induction of glucose-regulated protein 78 by chronic hypoxia in human gastric tumor cells through a protein kinase C-epsilon/ERK/AP-1 signaling cascade. Cancer Res 2001, 61:8322-8330.

50. Sun S, Han J, Ralph WM Jr, Chandrasekaran A, Liu K, Auborn KJ, Carter TH: Endoplasmic reticulum stress as a correlate of cytotoxicity in human tumor cells exposed to diindolylmethane in vitro. Cell Stress Chaperones 2004, 9:76-87.

51. Chen Xiaoxin, Ding Yu, Chang-Gong Liu, and SM, Yang CS: Overexpression of glucose-regulated protein 94 (Grp94) in esophageal adenocarcinomas of a rat surgical model and humans. Carcinogenesis 2002, 23:123-130.

52. Ye J, Koumenis C: ATF4, an ER stress and hypoxia-inducible transcription factor and its potential role in hypoxia tolerance and tumorigenesis. Curr Mol Med 2009, 9:411-416.

53. Goldstein MG, Li Z: Heat-shock proteins in infection-mediated inflammation-induced tumorigenesis. J Hematol Oncol 2009, 2:5.

54. Qu L, Huang S, Baltzis D, Rivas-Estilla AM, Pluquet O, Hatzoglou M, Koumenis C, Taya Y, Yoshimura A, Koromilas AE: Endoplasmic reticulum stress induces p53 cytoplasmic localization and prevents p53-dependent apoptosis by a pathway involving glycogen synthase kinase-3beta. Genes Dev 2004, 18:261-277.

55. Kitamura M: Biphasic, bidirectional regulation of NF-kappaB by endoplasmic reticulum stress. Antioxid Redox Signal 2009, 11:2353-2364

56. Jolly C, Morimoto Rl: Role of the heat shock response and molecular chaperones in oncogenesis and cell death. J Natl Cancer Inst 2000, 92:1564-1572.

57. So A, Hadaschik B, Sowery R, Gleave M: The role of stress proteins in prostate cancer. Curr Genomics 2007, 8:252-261.

58. Dong D, Ni M, Li J, Xiong S, Ye W, Virrey JJ, Mao C, Ye R, Wang M, Pen L, et al: Critical role of the stress chaperone GRP78/BiP in tumor proliferation, survival, and tumor angiogenesis in transgene-induced mammary tumor development. Cancer Res 2008, 68:498-505.

59. Lee AS: GRP78 induction in cancer: therapeutic and prognostic implications. Cancer Res 2007, 67:3496-3499.

60. Li J, Lee AS: Stress induction of GRP78/BiP and its role in cancer. Curr Mol Med 2006, 6:45-54

61. Al-Rawashdeh FY, Scriven P, Cameron IC, Vergani PV, Wyld L: Unfolded protein response activation contributes to chemoresistance in hepatocellular carcinoma. Eur J Gastroenterol Hepatol 22:1099-1105.

62. Eunjung Lee PN, Spicer Darcy, Groshen Susan, Yu Mimi C, Lee Amy S: GRP78 as a Novel Predictor of Responsiveness Chemotherapy in Breast Cancer. Cancer Res 2006, 66:7849.

63. Fu Y, Lee AS: Glucose regulated proteins in cancer progression, drug resistance and immunotherapy. Cancer Biol Ther 2006, 5:741-744.

64. Uramoto H, Sugio K, Oyama T, Nakata S, Ono K, Yoshimastu T, Morita M, Yasumoto K: Expression of endoplasmic reticulum molecular chaperone Grp78 in human lung cancer and its clinical significance. Lung Cancer 2005, 49:55-62

65. Scriven P, Coulson S, Haines R, Balasubramanian S, Cross S, Wyld L: Activation and clinical significance of the unfolded protein response in breast cancer. Br J Cancer 2009, 101:1692-1698.

66. Wang Q, He Z, Zhang J, Wang Y, Wang T, Tong S, Wang L, Wang S, Chen $Y$ : Overexpression of endoplasmic reticulum molecular chaperone GRP94 and GRP78 in human lung cancer tissues and its significance. Cancer Detect Prev 2005, 29:544-551.
67. Langer R, Feith M, Siewert JR, Wester HJ, Hoefler H: Expression and clinical significance of glucose regulated proteins GRP78 (BiP) and GRP94 (GP96) in human adenocarcinomas of the esophagus. BMC Cancer 2008, 8:70.

68. Zheng HC, Takahashi H, Li XH, Hara T, Masuda S, Guan YF, Takano Y: Overexpression of GRP78 and GRP94 are markers for aggressive behavior and poor prognosis in gastric carcinomas. Hum Pathol 2008, 39:1042-1049.

69. Jamora C, Dennert G, Lee AS: Inhibition of tumor progression by suppression of stress protein GRP78/BiP induction in fibrosarcoma B/ C10ME. Proc Natl Acad Sci USA 1996, 93:7690-7694

70. Davies MP, Barraclough DL, Stewart C, Joyce KA, Eccles RM, Barraclough R, Rudland PS, Sibson DR: Expression and splicing of the unfolded protein response gene XBP-1 are significantly associated with clinical outcome of endocrine-treated breast cancer. Int J Cancer 2008, 123:85-88.

71. Gomez BP, Riggins RB, Shajahan AN, Klimach U, Wang A, Crawford AC, Zhu Y, Zwart A, Wang M, Clarke R: Human X-box binding protein-1 confers both estrogen independence and antiestrogen resistance in breast cancer cell lines. Faseb J 2007, 21:4013-4027.

72. Carrasco DR, Sukhdeo K, Protopopova M, Sinha R, Enos M, Carrasco DE, Zheng M, Mani M, Henderson J, Pinkus GS, et al: The differentiation and stress response factor XBP-1 drives multiple myeloma pathogenesis. Cancer Cell 2007, 11:349-360.

73. Obeng EA, Carlson LM, Gutman DM, Harrington WJ Jr, Lee KP, Boise LH: Proteasome inhibitors induce a terminal unfolded protein response in multiple myeloma cells. Blood 2006, 107:4907-4916.

74. Sterz JSO: The potential of proteasome inhibitors in cancer therapy. Expert Opin Investig Drugs 2008, 17:879-895.

75. Hoseki J, Ushioda R, Nagata K: Mechanism and components of endoplasmic reticulum-associated degradation. J Biochem 2010 147:19-25.

76. Wang Q, Li L, Ye Y: Inhibition of p97-dependent protein degradation by Eeyarestatin I. J Biol Chem 2008, 283:7445-7454.

77. Lu DP, Christopher DA: Endoplasmic reticulum stress activates the expression of a sub-group of protein disulfide isomerase genes and AtbZIP60 modulates the response in Arabidopsis thaliana. Mol Genet Genomics 2008, 280:199-210.

78. Townsend DM, Manevich Y, He L, Xiong Y, Bowers RR Jr, Hutchens S, Tew KD: Nitrosative stress-induced s-glutathionylation of protein disulfide isomerase leads to activation of the unfolded protein response. Cancer Res 2009, 69:7626-7634.

79. Davenport EL, Moore HE, Dunlop AS, Sharp SY, Workman P, Morgan GJ, Davies FE: Heat shock protein inhibition is associated with activation of the unfolded protein response pathway in myeloma plasma cells. Blood 2007, 110:2641-2649.

80. Banerji U, Judson I, Workman P: The clinical applications of heat shock protein inhibitors in cancer - present and future. Curr Cancer Drug Targets 2003, 3:385-390.

81. Mimnaugh EG, Xu W, Vos M, Yuan X, Isaacs JS, Bisht KS, Gius D, Neckers L: Simultaneous inhibition of hsp 90 and the proteasome promotes protein ubiquitination, causes endoplasmic reticulum-derived cytosolic vacuolization, and enhances antitumor activity. Mol Cancer Ther 2004, 3:551-566.

82. Mimnaugh EG, Xu W, Vos M, Yuan X, Neckers L: Endoplasmic reticulum vacuolization and valosin-containing protein relocalization result from simultaneous hsp90 inhibition by geldanamycin and proteasome inhibition by velcade. Mol Cancer Res 2006, 4:667-681.

83. Solit DB, Osman I, Polsky D, Panageas KS, Daud A, Goydos JS, Teitcher J, Wolchok JD, Germino FJ, Krown SE, et al: Phase II trial of 17-allylamino-17demethoxygeldanamycin in patients with metastatic melanoma. Clin Cancer Res 2008, 14:8302-8307.

84. Usmani SZ, Bona RD, Chiosis G, Li Z: The anti-myeloma activity of a novel purine scaffold HSP90 inhibitor PU-H71 is via inhibition of both HSP90A and HSP90B1. J Hematol Oncol 3:40.

85. Pyrko P, Schonthal AH, Hofman FM, Chen TC, Lee AS: The unfolded protein response regulator GRP78/BiP as a novel target for increasing chemosensitivity in malignant gliomas. Cancer Res 2007, 67:9809-9816

86. Park HRTA, Sato S, Tsukumo Y, Yun J, Yamori T, Hayakawa Y, Tsuruo T, Shinya K: Effect on tumor cells of blocking survival response to glucose deprivation. J Natl Cancer Inst 2004, 96(17):1300-10. 
87. Matsuo J, Tsukumo Y, Sakurai J, Tsukahara S, Park HR, Shin-Ya K, Watanabe T, Tsuruo T, Tomida A: Preventing the unfolded protein response via aberrant activation of $4 \mathrm{E}$-binding protein 1 by versipelostatin. Cancer Sci 2008.

88. Saito S, Furuno A, Sakurai J, Sakamoto A, Park HR, Shin-Ya K, Tsuruo T, Tomida A: Chemical genomics identifies the unfolded protein response as a target for selective cancer cell killing during glucose deprivation. Cancer Res 2009, 69:4225-4234.

89. Shin-Ya K: Novel antitumor and neuroprotective substances discovered by characteristic screenings based on specific molecular targets. Biosci Biotechnol Biochem 2005, 69:867-872.

90. Backer JM, Krivoshein AV, Hamby CV, Pizzonia J, Gilbert KS, Ray YS, Brand H, Paton AW, Paton JC, Backer MV: Chaperone-targeting cytotoxin and endoplasmic reticulum stress-inducing drug synergize to kill cancer cells. Neoplasia 2009, 11:1165-1173.

91. Koong DFaAC: Irestatin, a potent inhibitor of IRE1 and the unfolded protein response, is a hypoxia-selective cytotoxin and impairs tumor growth. Journal of Clinical Oncology, 2007 ASCO Annual Meeting Proceedings (Post-Meeting Edition) 2007, 25:3514.

92. Futamura $Y$, Tashiro E, Hironiwa N, Kohno J, Nishio M, Shindo K, Imoto M: Trierixin, a novel Inhibitor of ER stress-induced XBP1 activation from Streptomyces sp. II. structure elucidation. J Antibiot (Tokyo) 2007, 60:582-585.

93. Patterson J, Palombella VJ, Fritz C, Normant E: IPI-504, a novel and soluble HSP-90 inhibitor, blocks the unfolded protein response in multiple myeloma cells. Cancer Chemother Pharmacol 2008, 61:923-932.

94. Salazar M, Carracedo A, Salanueva IJ, Hernandez-Tiedra S, Lorente M, Egia A, Vazquez P, Blazquez C, Torres S, Garcia S, et al: Cannabinoid action induces autophagy-mediated cell death through stimulation of ER stress in human glioma cells. J Clin Invest 2009, 119:1359-1372.

95. Liu BQ, Gao YY, Niu XF, Xie JS, Meng X, Guan Y, Wang HQ: Implication of unfolded protein response in resveratrol-induced inhibition of $\mathrm{K} 562$ cell proliferation. Biochem Biophys Res Commun 2009, 391:778-782.

96. Banjerdpongchai $R$, Kongtawelert $P$, Khantamat O, Srisomsap C, Chokchaichamnankit D, Subhasitanont P, Svasti J: Mitochondrial and endoplasmic reticulum stress pathways cooperate in zearalenoneinduced apoptosis of human leukemic cells. J Hematol Oncol 3:50.

97. San Miguel JF, Schlag R, Khuageva NK, Dimopoulos MA, Shpilberg O, Kropff M, Spicka I, Petrucci MT, Palumbo A, Samoilova OS, et al: Bortezomib plus melphalan and prednisone for initial treatment of multiple myeloma. N Engl J Med 2008, 359:906-917.

98. Chauhan D, Singh AV, Ciccarelli B, Richardson PG, Palladino MA, Anderson KC: Combination of novel proteasome inhibitor NPI-0052 and lenalidomide trigger in vitro and in vivo synergistic cytotoxicity in multiple myeloma. Blood 115:834-845.

99. O'Connor OA, Stewart AK, Vallone M, Molineaux CJ, Kunkel LA, Gerecitano JF, Orlowski RZ: A phase 1 dose escalation study of the safety and pharmacokinetics of the novel proteasome inhibitor carfilzomib (PR171 ) in patients with hematologic malignancies. Clin Cancer Res 2009, 15:7085-7091.

100. Lee AFW P, Burris HA III, Papadopoulos K, Sausville EA, Rosen PJ, Mendelson DS, Infante JR, Patnaik A, Gordon MS: Updated results of a phase Ib/II study of carfilzomib (CFZ) in patients (pts) with relapsed malignancies. Journal of Clinical Oncology, 2010 ASCO Annual Meeting Proceedings (Post-Meeting Edition) 2010, 28:8147.

101. Paul G, Richardson BB, Berenson James: Phase II study of the proteasome inhibitor PS-341 in multiple myeloma (MM) patients (pts) with relapsed/ refractory disease. Proc Am Soc Clin Oncol 2002, 21(abstr 40).

102. Roberto Piva BR, Williams Michael: CEP-18770: A novel, orally active proteasome inhibitor with a tumor-selective pharmacologic profile competitive with bortezomib. Blood 2008, 111(5):2765-2775.

103. Richardson PG, Badros AZ, Jagannath S, Tarantolo S, Wolf JL, Albitar M, Berman D, Messina M, Anderson KC: Tanespimycin with bortezomib: activity in relapsed/refractory patients with multiple myeloma. $\mathrm{Br} \mathrm{J}$ Haematol 150:428-437.

104. Richardson PG, Chanan-Khan AA, Alsina M, Albitar M, Berman D, Messina M, Mitsiades CS, Anderson KC: Tanespimycin monotherapy in relapsed multiple myeloma: results of a phase 1 dose-escalation study. $\mathrm{Br} \mathrm{J}$ Haematol 150:438-445.

105. Heath El, Hillman DW, Vaishampayan U, Sheng S, Sarkar F, Harper F, Gaskins M, Pitot HC, Tan W, Ivy SP, et al: A phase II trial of 17-allylamino- 17-demethoxygeldanamycin in patients with hormone-refractory metastatic prostate cancer. Clin Cancer Res 2008, 14:7940-7946.

106. Pacey S, Gore M, Chao D, Banerji U, Larkin J, Sarker S, Owen K, Asad Y, Raynaud F, Walton $M$, et al: A Phase II trial of 17-allylamino, 17demethoxygeldanamycin (17-AAG, tanespimycin) in patients with metastatic melanoma. Invest New Drugs 2010.

107. Kummar S, Gutierrez ME, Gardner ER, Chen X, Figg WD, Zajac-Kaye M Chen M, Steinberg SM, Muir CA, Yancey MA, et al: Phase I trial of 17dimethylaminoethylamino-17-demethoxygeldanamycin (17-DMAG), a heat shock protein inhibitor, administered twice weekly in patients with advanced malignancies. Eur J Cancer 46:340-347.

108. Lancet JE, Gojo I, Burton M, Quinn M, Tighe SM, Kersey K, Zhong Z, Albitar MX, Bhalla K, Hannah AL, Baer MR: Phase I study of the heat shock protein 90 inhibitor alvespimycin (KOS-1022, 17-DMAG) administered intravenously twice weekly to patients with acute myeloid leukemia. Leukemia 24:699-705.

109. Ramanathan RK, Egorin MJ, Erlichman C, Remick SC, Ramalingam SS, Naret C, Holleran JL, TenEyck CJ, Ivy SP, Belani CP: Phase I pharmacokinetic and pharmacodynamic study of 17-dimethylaminoethylamino-17demethoxygeldanamycin, an inhibitor of heat-shock protein 90 , in patients with advanced solid tumors. J Clin Oncol 28:1520-1526.

110. V. Zismanov LD, Gottfried M: Targeting ER-Golgi homeostasis as a therapeutic strategy in lung cancer. J Clin Oncol 2010, suppl; abstr e21030.

111. Hanson BE, Vesole DH: Retaspimycin hydrochloride (IPI-504): a novel heat shock protein inhibitor as an anticancer agent. Expert Opin Investig Drugs 2009, 18:1375-1383.

112. Caldas-Lopes E, Cerchietti L, Ahn JH, Clement CC, Robles Al, Rodina A, Moulick K, Taldone T, Gozman A, Guo Y, et al: Hsp90 inhibitor PU-H71, a multimodal inhibitor of malignancy, induces complete responses in triple-negative breast cancer models. Proc Natl Acad Sci USA 2009, 106:8368-8373.

113. Marubayashi S, Koppikar P, Taldone T, Abdel-Wahab O, West N, Bhagwat N, Caldas-Lopes E, Ross KN, Gonen M, Gozman A, et al: HSP90 is a therapeutic target in JAK2-dependent myeloproliferative neoplasms in mice and humans. J Clin Invest 120:3578-3593.

114. T. Bachleitner-Hofmann MYS, Chen C, Zeng Z: ntitumor activity of SNX2112, a synthetic heat shock protein 90 inhibitor, in malignancies with amplification of the MET oncogene. J Clin Oncol 2010, 28(suppl; abstr e13561).

115. Cross BC, McKibbin C, Callan AC, Roboti P, Piacenti M, Rabu C, Wilson CM, Whitehead R, Flitsch SL, Pool MR, et al: Eeyarestatin I inhibits Sec61mediated protein translocation at the endoplasmic reticulum. J Cell Sci 2009, 122:4393-4400

116. Luo T, Wang J, Yin $Y$, Hua $H$, Jing J, Sun $X$, Li M, Zhang $Y$, Jiang Y: (-)-Epigallocatechin gallate sensitizes breast cancer cells to paclitaxel in a murine model of breast carcinoma. Breast Cancer Res 12:R8.

117. D. Feldman ACK: Irestatin, a potent inhibitor of IRE1a and the unfolded protein response, is a hypoxia-selective cytotoxin and impairs tumor growth. In Journal of Clinical Oncology. Volume 25. ASCO Annual Meeting Proceedings Part I; 2007:(18S (June 20 Supplement)):3514, 2007.

118. Guzman M, Duarte MJ, Blazquez C, Ravina J, Rosa MC, Galve-Roperh I, Sanchez C, Velasco G, Gonzalez-Feria L: A pilot clinical study of Delta9tetrahydrocannabinol in patients with recurrent glioblastoma multiforme. Br J Cancer 2006, 95:197-203.

doi:10.1186/1756-8722-4-8

Cite this article as: Li et al:: Unfolded protein response in cancer: the Physician's perspective. Journal of Hematology \& Oncology 2011 4:8. 